\title{
Interest Groups, Public Expenditure, and Economic Grow th: An Empirical Investigation
}

\author{
Eunji Kim* and Sangheon Kim**
}

\begin{abstract}
Although many studies have dealt with the relationship between government expenditure and economic growth, none has been able to pinpoint its exact nature. Recently, however, new efforts have been made to find new factors or variables that moderate the relationship. This paper investigates a new moderating variable, interest group activity, as suggested by Kim (forthcoming). According to cross-country data analysis, the interaction term between government expenditure and interest group activity plays a significant role. Government expenditure has been estimated to have a positive effect on economic growth when interest groups are inactive, and a negative impact on growth when interest groups are active.
\end{abstract}

Keywords: interest groups, public expenditure, economic growth

\section{INTRODUCTION}

There is no doubt that economic growth has been a major field of economics, ever since economics began attracting scholars as a subject of social science, and remains one of its most important issues. Economic crises in recent years have inspired increasing attention to growth by both citizens and academicians. Many great scholars have tried to understand the various aspects of growth. One of the main foci might be on what causes economic growth, trying to answer the question of why some countries have experienced economic growth and others have not.

Earlier generations considered traditional factors such as physical capital and population to be the main components of production functions (Solow, 1957; Swan, 1956).

\footnotetext{
* Eunji Kim is an M.A. candidate at the Graduate School of Public Administration, Seoul National University. E-mail: transcendent@snu.ac.kr.

** Sangheon Kim (corresponding author) is an associate professor at the Graduate School of Public Administration, Seoul National University. E-mail: sanghkim@snu.ac.kr.
}

Manuscript received November 4, 2011; out for review November 8, 2011; review completed December 16, 2011; accepted December 20, 2011. 
Neoclassical growth theory pioneered by Solow and Swan arose as a reaction to the Harrod-Domar models of the 1904s and 1950s (Harrod, 1939; Domar, 1946). Since then, we have witnessed a great many theories concerning economic growth. Some emphasized behaviorist tradition (Samuelson \& Modigliani, 1966; Bertola, 1994), and others considered growth as an optimizing problem (Cass, 1965; Koopmans, 1965). Later generations paid attention to endogenous characteristics of growth (Lucas, 1988; Romer, 1990). Shultz (1961) and Becker (1975) noted the importance of the quality of labor - as affected by education, training, health, and other factors-for economic growth.

Advances in economic growth theory have generated various empirical studies. So many variables have been included in regression equations of economic growth that it might be hard to think of a new independent variable. ${ }^{1}$ Sala-i-Martin (1997) suggested 23 variables that were estimated to have robust influences on economic growth.

Notwithstanding the number of theoretical and empirical studies of economic growth, it is difficult to find any work relating interest group activity to growth, even though its importance was emphasized long time ago by Olson (1965), who suggested the notable idea that the degree of activation of interest groups affects economic growth. In the meantime, a number of studies have dealt with the effects of government expenditure on growth. These studies, however, focused on the linear relationship between the two. This paper intends to fill a gap in the empirical growth literature by investigating the relationship of interest group activity, government expenditure, and economic growth. More specifically, it tests the effect of the interaction between interest group activity and government expenditure on growth, using cross-country data.

The rest of the paper is organized as follows. The next section reviews the literature on the relationship of government expenditure and economic growth and provides the point of departure for this study. The following section suggests an empirical model and data for the estimation of the model. Next, estimation results are presented, followed by conclusions and a brief discussion of the limits of the study.

\section{LITERATURE}

The relationship between government spending and economic growth has been studied for a long time, and the results are very diverse. The studies more directly related to this paper are those dealing with the association of government size and

1. Durlauf and Quah (1999) summarize these variables well. The total number of variables is 83 . 
economic growth. ${ }^{2}$ Those studies have focused on four main issues: whether a negative or positive relationship exists between government size and economic growth, whether there is an inverted- $U$ relationship, the causal relationship between government size and economic growth, and whether total government spending or specific categories of spending are more important.

Whether a positive or negative relationship exists between government expenditure and economic growth was a major theme in early studies on this topic; the issue of the inverted-U relationship between them also attracted many scholars' attention. Those who empirically examined the relationship between government size and economic growth mostly focused on the linear relationship between the two. In other words, they tried to verify whether government spending affects the economy positively or negatively. Unfortunately, however, even these studies on the linear relationship between them have not agreed upon a definitive answer. Landau (1983), Grier and Tullock (1989), Scully (1989), Grossman (1990), Folster and Henrekson (1999, 2001), and Mueller and Stratmann (2003) have concluded that government size has a negative impact on economic growth. In contrast, Ram (1986) and Aschauer (1989) argued for a positive association.

The second category of research on the relationship between government size and economic growth is concerned with the endogeneity problem of government size. This kind of inquiry had been ignored in the field for a long time. Recently, however, we began to witness studies dealing with the endogeneity problem explicitly (Folster \& Henrekson, 2001; Agell, Ohlsson, \& Thoursie, 2006; Angelopoulos \& Philippopoulos, 2007). Folster and Henrekson (2001) used the previous-period total government share as an instrumental variable to solve the problem of endogeneity. Agell, Ohlsson, and Thoursie (2006), however, pointed out that the instrumental variable used by Folster and Henrekson (2001) was invalid. They suggested using two-period-before values as instruments, since using one-period-before values have correlation with error terms because the independent variable is a differenced one. On the other hand, Angelopoulos and Philippopoulos (2007) used political regime dummies at the year before election years as an instrument.

The third area of research has tried to investigate the relationship between government spending and economic growth with an emphasis on the idea that government spending in specific fields is more important than the total size of government expenditure. Some of them also argue that the effect of government size on growth is likely to depend on the kinds of revenue sources. Typical examples of such studies include

2. Government size is usually defined as government expenditure divided by the gross domestic product. 
Barro (1997), Bovenberg and Smulders (1996), and Kneller, Bleaney, and Gemmel (1999). According to Barro (1997), education, research and development, and health spending generate the effect of capital accumulation and therefore contribute to economic growth, unlike other categories of government expenditures such as current expenditures. Among current expenditures, however, the expenditures for property rights protection or safety have been reported to stimulate economic growth.

Bovenberg and Smulders (1996) claimed government spending on the environment helped the economy to grow. Kneller, Bleaney, and Gemmel (1999) categorized government spending as either productive or nonproductive, and then showed that the former had positive impacts on economic growth whereas the latter affected it adversely. In addition, they divided taxes into two categories, distortionary and nondistortionary, and estimated the effects of each. They concluded that the former resulted in a negative effect and the latter in a positive effect.

Views are divided on the effect of social security expenditures. De Groot (2000) claimed social security spending led to a reduction in labor supply and had a negative impact on economic growth because it entailed distortionary taxes. In contrast, Bellettini and Ceroni (2000) argued that social security spending played a positive role because it helped to accumulate human capital.

More recently, several meaningful studies have attempted to find new variables that were missing in the regression equation of economic growth on government expenditure. Monte and Papagni (2001) included corruption as a new independent variable and inserted the interaction term of corruption and government spending as a control variable. Guseh (1997) included social systems (market system, socialist system, and democratic system) as independent variables. Plumper and Martin (2003) investigated how the degree of democracy and the degree of political participation affected the economy. Angelopoulos and Philippopoulos (2007), using Greek data, showed that the relative efficiency of the public sector had different impacts on economic growth. They found that when efficiency was low, an increase in the government size harmed the economy, with the opposite result when efficiency was high.

As shown above, the relationship between government spending and economic growth is an old topic in the field of economic growth. The studies most directly related to this paper are those emphasizing specific categories of government expenditure rather than the total amount. These studies show that some types of government spending have an adverse effect on the economy whereas other types have the capacity to improve the economy. The criteria for classifying and choosing types of government spending to focus on, however, have been naive and arbitrary. For instance, Kneller, Bleaney, and Gemmel's (1999) classification of productive and nonproductive spending seems to be entirely dependent on the authors' own discretion. It is hard to see any 
theoretical justification for the classification.

In this context, Kim (forthcoming) provides a new step toward a theoretical justification for adopting a criterion for government expenditure classification. He shows that interest group activity might be a moderator variable in the investigation of the effect of government expenditure on economic growth. More specifically, he proves that the more active the interest groups, the more government expenditures tend to have adverse impacts on the economy, other things being equal. Departing from that point, this study tests whether the interaction term between interest group activity and government expenditure plays any role in the growth equation.

\section{METHODOLOGY}

\section{Empirical Model}

The previous section emphasized that in order to estimate the effects of government expenditure on economic growth, the interest group activity variable should be included as a moderator variable. With this fact in mind, this section specifies a regression model.

Since the focus is on the effects of government expenditure on economic growth, the economic growth rate needs to be included as the dependent variable. For the same reason, government expenditure should be included as an independent variable. To estimate the influence of the moderator variable, interest group activity, the interaction term of government expenditure and interest group activity also needs to be inserted in the regression equation.

For the exact estimation of the effects of these two main independent variables, other factors should be controlled for that affect the dependent variable, economic growth rate. First of all, capital and labor might have an influence on economic growth, since it is well known that output is a function of capital and labor. It has also been reported many times that the initial GDP per capita can have a negative effect on growth rate: full-fledged economies have slower rates of economic growth than growing ones.

The discussion up to now implies a regression equation as follows:

$$
\text { growth }=\beta_{0}+\beta_{1} \text { govexp }+\beta_{2} \text { govexp } \times \text { interest }+X \beta+\varepsilon,
$$

where growth, govexp, and interest mean economic growth rate, government expenditure, and interest group activity, respectively. Other control variables are in the $X$ 
vector and the last term, $\varepsilon$, denotes errors.

If the assumptions for the ordinary least square (OLS) method are all met, estimating equation (1) is simple and straightforward. It is possible, however, that interest group activity is influenced by economic conditions. Olson (1965) argued that advanced economies are more likely to have strong and active interest groups than others. If this view is accepted, one of the OLS estimation assumptions is violated: exogeneity of independent variables. When interest group activity is endogenous, estimating equation (1) might result in biased estimates. The endogeneity problem can be addressed by a simultaneous estimation of the following equation together with equation (1).

$$
\text { interest }=Z \gamma+\omega
$$

where $Z$ is a vector of factors affecting interest group activity and $\omega$ is the error term. The main variable in $Z$ will be GDP per capita, following Olson (1965). Equations (1) and (2) can be estimated simultaneously with the two-stage least square, the three-stage least square, the limited information maximum likelihood, or the full information maximum likelihood technique.

\section{Data}

For the dependent variable, economic growth, the growth rates of GDP per capita reported by the United Nations (UN) are used. The UN's growth rates are based on current prices measured in US dollars.

The UN also publishes government expenditures across countries. Government expenditure divided by GDP is included in the equation as a major independent variable. The second key variable is the interaction term between government expenditure and interest group activity. The World Economic Forum measured and published intensities of interest group activity for various countries in 1999 (based on 1998 data). To be more concrete, the variable measures how independently economic policies are decided from the pressure of interest groups. The scale is from 1 to 7: the higher the number, the more independent the government's economics policies are from interest groups' pressure. Therefore, it can be said that this variable is more concerned with activities of self-interest-oriented groups than with those of general-purpose groups such as civil rights groups. The coefficients of these two variables cannot be known a priori, and they will be the main interest of this study.

It has been shown above that for the exact estimation of the effects of independent variables on economic growth, the initial economic condition should be controlled for. For this purpose, GDP per capita in 1970 is included, data for which also come from 
the UN. It is expected that the coefficient of this variable is negative.

Other control variables are capital and population. The growth rates of gross capital formation and population, which are released by the UN, are used. Capital formation is measured in 1990 prices. For the estimation of equation (2), GDP per capita is included as the independent variable. The UN provides GDP per capita across nations. Olson (1965) predicted that the variable would have a positive coefficient.

Variables and data sources described up to now are summarized in table 1.

Table 1. Variables and Data Sources

\begin{tabular}{l|l|l|l|c}
\hline \multicolumn{1}{c|}{ Variable } & \multicolumn{1}{c|}{ Definition } & \multicolumn{1}{c|}{ Period } & \multicolumn{1}{c}{ Source } & Expected sign \\
\hline growth & Growth rate of GDP per capita & $1998-1999$ & United Nations & \\
\hline govexp & $\begin{array}{l}\text { Government expenditure divided } \\
\text { by GDP }\end{array}$ & 1998 & United Nations & $?$ \\
\hline interest & $\begin{array}{l}\text { Influence of interest groups on } \\
\text { economic policies }\end{array}$ & 1998 & World Economic Forum & $?$ \\
\hline interest_gov & $\begin{array}{l}\text { Interaction term of interest group } \\
\text { and government expenditure }\end{array}$ & 1998 & $\begin{array}{l}\text { World Economic Forum } \\
\text { United Nations }\end{array}$ & $?$ \\
\hline initial GDP & GDP per capita in 1970 & 1970 & United Nations & - \\
\hline capital & Growth rate of capital formation & $1998-1999$ & United Nations & + \\
\hline population & Growth rate of population & $1998-1999$ & United Nations & + \\
\hline GDP & GDP per capita & 1998 & United Nations & + \\
\hline
\end{tabular}

Table 2 shows descriptive statistics for the variables used in the estimation of regression equations.

Table 2. Descriptive Statistics

\begin{tabular}{c|r|r|r|r}
\hline Variable name & \multicolumn{1}{|c|}{ M ean } & Standard deviation & M inimum & \multicolumn{1}{c}{ Maximum } \\
\hline growth & 0.0692 & 0.1585 & -0.6745 & 2.2586 \\
\hline govexp & 21.1695 & 9.9566 & 2.0690 & 77.8404 \\
\hline interest & 3.4475 & 0.6927 & 2.0600 & 5.5400 \\
\hline interest_gov & 65.1877 & 29.5266 & 21.4620 & 219.5057 \\
\hline initial GDP & 895.7429 & $1,072.4900$ & 42.0000 & $4,878.0000$ \\
\hline capital & 0.0592 & 2.2585 & -0.8936 & 7.4937 \\
\hline population & 0.0230 & 0.7388 & -0.1521 & 49.0763 \\
\hline GDP & $7,171.2300$ & $10,101.6400$ & 97.0000 & $45,733.0000$ \\
\hline
\end{tabular}




\section{ESTIMATION RESULTS}

Table 3 summarizes estimation results with the OLS method. First of all, model 1-1 and model 1-2 have similar results. As can be seen in the table, all the variables have the expected signs in both model 1-1 and model 1-2 except for the initial GDP per capita. The growth rate of capital formation is statistically significant at the 0.01 level regardless of the models. The coefficient of the interaction term between interest group activity and government expenditure is different from zero at the 0.10 significance level in the two models.

Table 3. OLS Results

\begin{tabular}{|c|c|c|c|}
\hline Dependent variable & Independent variable & Model 1-1 & M odel 1-2 \\
\hline \multirow{6}{*}{ growth } & constant & $\begin{array}{c}-0.13^{* * *} \\
(0.05)\end{array}$ & $\begin{array}{c}-0.11^{* * *} \\
(0.04)\end{array}$ \\
\hline & govexp & $\begin{array}{l}-3.74 E-3 \\
(4.13 E-3)\end{array}$ & $\begin{array}{l}-3.53 \mathrm{E}-3 \\
(4.11 \mathrm{E}-3)\end{array}$ \\
\hline & interest_gov & $\begin{array}{l}1.69 \mathrm{E}-3 * \\
(9.83 \mathrm{E}-4)\end{array}$ & $\begin{array}{l}1.63 \mathrm{E}-3 * * \\
(9.77 \mathrm{E}-4)\end{array}$ \\
\hline & initial GDP & $\begin{array}{c}1.66 E-5 \\
(1.07 E-5) \\
\end{array}$ & $\begin{array}{c}1.35 \mathrm{E}-5 \\
(9.89 \mathrm{E}-6) \\
\end{array}$ \\
\hline & capital & $\begin{array}{c}0.46^{* * *} \\
(0.06)\end{array}$ & $\begin{array}{c}0.44 * * * \\
(0.06)\end{array}$ \\
\hline & population & $\begin{array}{c}1.41 \\
(1.72)\end{array}$ & \\
\hline \multicolumn{2}{|l|}{ R-square } & 0.61 & 0.60 \\
\hline \multicolumn{2}{|l|}{ Adjusted R-square } & 0.56 & 0.57 \\
\hline \multicolumn{2}{|c|}{ Number of observations } & 53 & 53 \\
\hline
\end{tabular}

Note: Numbers in parentheses represent standard errors.

$*, * *, * * *=$ statistically significant at $10 \%, 5 \%$, and $1 \%$ respectively.

Government expenditure has a negative coefficient, and therefore the bigger the government share of GDP, the slower the economic growth. This is consistent with many previous studies that showed a negative relationship between government size (government expenditure divided by GDP) and economic growth. ${ }^{3}$

The table above, however, contains more information than the previous studies. Since the interaction term between interest group activity and government share is

3. Studies include those by Landau (1983), Grier and Tullock (1989), Scully (1989), Grossman (1990), Folster and Henrekson (1999, 2001), and Mueller and Stratmann (2003). 
positive, the relationship between government share and economic growth is not simply negative, which most of the previous studies have tended to show. The exact effect of government share on economic growth is dependent on the level of interest group activity. It can be expressed as

$$
\frac{\partial(\text { govexp })}{\partial(\text { govexp })}=\beta_{1}+\beta_{2} \times \text { interest }
$$

where $\beta_{1}$ and $\beta_{2}$ denote the coefficients for govexp and interest_gov, respectively.

For instance, the estimates from model 1-1 imply that

$$
\frac{\partial(\text { growth })}{\partial(\text { growth })}=-3.74 E-3+1.69 E-3 \times \text { interest }
$$

Equation (4) means that the effect of government share on economic growth is negative where the interest group activity variable is less than 2.213. In contrast, the effect is positive where the interest group activity is bigger than 2.213. As explained in the previous section, the bigger the interest group activity variable, the more independent economic policies are from the pressure of interest groups. It can be concluded, therefore, that government expenditure has a positive effect on economic growth when interest groups are relatively inactive, whereas it has a negative impact on growth when interest groups are active.

Table 4 shows estimates of equation (1) and (2) carried out simultaneously with the three-stage method. This has been tried to resolve the possibility of endogeneity in the interest group variable. The estimates, however, are almost the same as those estimated with the OLS method. The signs and statistical significances do not change at all, whereas the magnitudes of estimates change to a slight extent. Government share has a negative sign, and the coefficient of the interaction term between interest group activity and government share is positive. Therefore, the same conclusion applies here as shown above: government expenditure has a positive effect on economic growth when interest groups are inactive, and a negative effect when interest groups are active.

To summarize, the estimation results are robust to estimation methods and model specifications. Government expenditure share of GDP has been estimated to have a negative coefficient. The interaction term between interest group activity and government expenditure share has a positive coefficient. The effect of government expenditure on economic growth is dependent on the level of interest group activity. This is different from the results of previous studies in that they have focused on the definite direction 
Table 4. Simultaneous Equation Estimation Results

\begin{tabular}{|c|c|c|c|}
\hline Dependent variable & Independent variable & Model 2-1 & M odel 2-2 \\
\hline \multirow{6}{*}{ growth } & constant & $\begin{array}{c}-1.33 * * * \\
(0.05)\end{array}$ & $\begin{array}{c}-0.11 * * \\
(0.04)\end{array}$ \\
\hline & govexp & $\begin{array}{l}-3.82 \mathrm{E}-3 \\
(4.13 \mathrm{E}-3)\end{array}$ & $\begin{array}{l}-3.41 \mathrm{E}-3 \\
(4.11 \mathrm{E}-3)\end{array}$ \\
\hline & interest_gov & $\begin{array}{l}\text { 1.71E-3* } \\
(9.83 E-4)\end{array}$ & $\begin{array}{l}1.60 \mathrm{E}-3 * \\
(9.77 \mathrm{E}-4)\end{array}$ \\
\hline & initial GDP & $\begin{array}{c}1.70 E-5 \\
(1.10 E-5)\end{array}$ & $\begin{array}{c}1.40 \mathrm{E}-5 \\
(9.89 \mathrm{E}-6)\end{array}$ \\
\hline & capital & $\begin{array}{c}0.46 * * * \\
(0.06)\end{array}$ & $\begin{array}{c}0.46 * * * \\
(0.06)\end{array}$ \\
\hline & population & $\begin{array}{c}1.41 \\
(1.72)\end{array}$ & \\
\hline \multirow{2}{*}{ interest } & constant & $\begin{array}{c}3.32 * * * \\
(0.13)\end{array}$ & $\begin{array}{c}3.2 * * * \\
(0.13)\end{array}$ \\
\hline & GDP & $\begin{array}{l}1.40 \mathrm{E}-5 * \\
(2.20 \mathrm{E}-6)\end{array}$ & $\begin{array}{l}1.30 \mathrm{E}-5 * \\
(7.21 \mathrm{E}-6)\end{array}$ \\
\hline \multicolumn{2}{|c|}{ System weighted R-square } & 0.44 & 0.43 \\
\hline \multicolumn{2}{|c|}{ Number of observations } & 53 & 53 \\
\hline
\end{tabular}

Note: Numbers in parentheses represent standard errors.

$*, * *, * * *=$ statistically significant at $10 \%, 5 \%$, and $1 \%$ respectively.

of the effect (negative or positive). This study has shown that government expenditure share helps economic growth where interest groups are inactive and has a negative impact on growth where interest groups are active.

\section{CONCLUSION}

Despite a long history of studies, scholars have not been able to pinpoint the exact relationship between government expenditure and economic growth. Recently, however, new efforts have been made to find new factors or variables that moderate the relationship. This study empirically tested a new moderating variable, interest group activity, as suggested by Kim (forthcoming). According to cross-country data analysis, the interaction term between government expenditure and interest group activity plays a significant role. In other words, government expenditure has a positive effect on economic growth when interest groups are inactive, and a negative impact on growth when interest groups are active.

It might be argued that the study is meaningful in that it showed the working mech- 
anism connecting interest group activity, government expenditure, and economic growth. The major limits of this paper, however, come from the data set. Because of the limited availability of interest group activity data, the observations covered only 53 nations. For this reason, it might be hard to generalize the conclusion until a better data set is obtained.

\section{REFERENCES}

Agell, J., Ohlsson, H., \& Thoursie, P. S. 2006. Growth effects of government expenditure and taxation in rich countries: A comment. European Economic Review, 50(1): 211-218.

Angelopoulos, K., \& Philippopoulos, A. 2007. The growth effects of fiscal policy in Greece 1960-2000. Public Choice, 131: 157-175.

Aschauer, D. A. 1989. Is public expenditure productive? Journal of Monetary Economics, 23: $177-200$.

Barro, R. J. 1997. Determinants of economic growth: A cross-country empirical study. Cambridge, MA: MIT Press.

Becker, G., 1975. Human capital (2nd ed.). New York: National Bureau of Economic Research, Columbia University Press.

Bellettini, G., \& Ceroni, C. B. 2000. Social security expenditure and economic growth: An empirical assessment. Research in Economics, 54: 249-275.

Bertola, G., 1994. Wages, profits and theories of growth. In L. Pasinetti and R. Solow (eds.), Economic growth and the structure of long-term development (pp. 90-108). New York: St. Martin's Press.

Bovenberg, A. L., \& Smulders, S. A. 1996. Transitional impacts of environmental policy in an endogenous growth model. International Economic Review, 37: 861-893.

Cass, D., 1965. Optimum growth in an aggregative model of capital accumulation. Review of Economic Studies, 32: 233-240.

de Groot, H. L. F. 2000. Growth, unemployment and deindustrialization. Cheltenham, UK: Edward Elgar.

Domar, E. 1946. Capital expansion, rate of growth and employment. Econometrica, 14: 137-147.

Durlauf, S. N., \& Quah, D. T. 1999. The new empirics of economic growth. In J. B. Taylor \& M. Woodford (eds.), Handbook of Macroeconomics. Elsevier.

Folster, S., \& Henrekson, M. 1999. Growth and the public sector: A critique of the critics. European Journal of Political Economy, 15: 337-358.

Folster S., \& Henrekson, M. 2001. Growth effects of government expenditure and 
taxation in rich countries. European Economic Review, 45: 1501-1520.

Grier, K. B., \& Tullock, G., 1989. An empirical analysis of cross-national economic growth, 1951-80. Journal of Monetary Economics, 24: 259-276.

Grossman, P. J., 1990. Government and growth: Cross-sectional evidence. Public Choice, 65: 217-227.

Guseh, J. S. 1997. Government size and economic growth in developing countries: A political-economy framework. Journal of Macroeconomics, 19: 175-192.

Harrod, R. 1939. An essay in dynamic theory. Economic Journal, 49:14-33.

Kim, S. forthcoming. Political economy of government expenditure and economic growth. Korean Journal of Public Finance.

Kneller R., Bleaney, M., \& Gemmel, N. 1999. Public policy and the government budget constraint: Evidence from the OECD. Journal of Public Economics, 74: 171-190.

Koopmans, T. C., 1965. On the concept of optimal economic growth. Scientific papers of Tjalling C. Koopmans. New York: Springer.

Landau, D. L., 1983. Government expenditure and economic growth: A cross-country study. Southern Economic Journal, 49: 783-792.

. 1985. Government expenditure and economic growth in the developed countries: 1952-76. Public Choice, 47: 459-477.

1986. Government and economic growth in the less developed countries: An empirical study for 1960-1980. Economic Development and Cultural Change, 35: 34-75.

Lucas, R. E., 1988. On the mechanics of economic development. Journal of Monetary Economics, 22: 3-42.

Monte, A. D., \& Papagni, E., 2001. Public expenditure, corruption, and economic growth: The case of Italy. European Journal of Political Economy, 17(1): 1-16.

Mueller, D. C., \& Stratmann, T. 2003. The economic effects of democratic participation. Journal of Public Economics, 87(9-10): 2129-2155.

Olson, M. 1965. The logic of collective action: Public goods and the theory of groups. Cambridge, MA: Harvard University Press.

Plumper, T., \& Martin, C. W. 2003. Democracy, government spending, and economic growth: A political-economic explanation of the Barro-effect. Public Choice, 117(1-2): 27-50.

Ram R., 1986. Government size and economic growth: A new framework and some evidence from cross-section and time-series data. American Economic Review, 76: 191-203.

Romer, P. M. 1990. Endogenous technological change. Journal of Political Economy, 98: S71-S102.

Sala-i-Martin, X. 1997. I just ran two million regressions. American Economic 
Review, 82(2): 178-183.

Samuelson, P. A., \& Modigliani, F. 1966. The Pasinetti paradox in neoclassical and more general models. Review of Economic Studies, 33: 269-301.

Schultz, T. W. 1961. Investment in human capital. American Economic Review, 51: 1-17.

Scully, G. W. 1989. The size of the state, economic growth and the efficient utilization of national resources. Public Choice, 63: 149-164.

Solow, R. M. 1957. Technical change and the aggregate production functions. Review of Economics and Statistics, 29: 312-320.

Swan, T. W. 1956. Economic growth and capital accumulation. Economic Record, 32: 334-361. 